\title{
The Use of Consonant Vowel Consonant (CVC) Word Game Strategy to Increase the Students' Vocabulary at the Second Grade at SMP Ujung Pandang Makassar
}

\author{
Arma Amir Hamzah, M. Dahlan Bahang*, Antonius Ali Wutun, Lina Arruan \\ English Department of Stkip-Ypup Makassar, South Celebes, Indonesia.
}

\begin{abstract}
How to cite this paper: Arma Amir Hamzah, M. Dahlan Bahang, Antonius Ali Wutun, Lina Arruan. (2020). The Use of Consonant Vowel Consonant (CVC) Word Game Strategy to Increase the Students' Vocabulary at the Second Grade at SMP Ujung Pandang Makassar. The Educational Review, USA, 4(10), 179-184.

DOI: 10.26855/er.2020.10.001
\end{abstract}

Received: August 12, 2020

Accepted: September 25, 2020

Published: October 21, 2020

Corresponding author: M. Dahlan Bahang, English Department of Stkip-Ypup Makassar, South Celebes, Indonesia.

Email: mdahlan.hbahang@gmail.com

\begin{abstract}
The objective of the research is to find out whether or not the use of consonant vowel consonant (CVC) word game strategy to increase the students' vocabulary at the second grade of SMP Ujung Pandang Makassar. The research applied pre-experimental method. The population of this research was the second grade students of SMP Ujung Pandang Makassar in 2018/2019 academic year, it consists of two classes VII 1 and VII 2, each class consist of 23 students. The total population was 46 students. The researcher used purposive sampling technique. The total sample of this research was 23 students. The result of the data analysis showed that the students' vocabulary achievement, in the pre-test was X1 $=55.5$ and the post-test was X2 $=82.06$. The result of the t-test value was (14.69) greater than the t-table value was (2.074). This indicates that the null hypothesis (H0) was rejected and the alternative hypothesis (H1) was accepted. In other word, after the treatment, it can be concluded that the mean score of the students' pre-test is smaller than the mean score of the students' post-test $(55.5<82.06)$. It means that the use of CVC word can increase the students' vocabulary mastery in English.
\end{abstract}

Keywords

CVC Word Game, Vocabulary Mastery

\section{Introduction}

Language is the most important aspect in human interaction because people use it for communication by using language. That is why many countries like Indonesia use the language of English in other to communicate with other people who have different languages. In supporting this idea, English language is very important to be taught and learned by the students. In order to respond this case, the Indonesian Government had used the English subject in our country educational system not only from primary education but until the university level.

As an international language, English has four basic skills that should mastered by the learners in learning English language. Those skills are listening, speaking, reading, and writing. Speaking and reading are included productive skills, while listening and reading are included receptive skills. In order to master those skills, the learners have to learn and understand and memorize vocabularies that they have learned before which become the first key in learning a language. In other word, vocabulary for the learners is regarded important, because the ability of the students in learning English 
is determined by the vocabulary that they have learned before. Through vocabulary, the students can communicate with their ideas, feeling, emotion and desire. It is sometimes smart students must stop their speaking because of lacking of vocabulary mastery. It is nonsense or very difficult for someone to express his or her ideas in English to other people without vocabulary.

Learning language as a foreign language seems easy but there are some problems that faced by the students to learn vocabulary such as feel fear, lack interest in learning and they faced difficult to remember the words (Rabbani, 2016). In generally, the problem faced by the students particularly in Junior High School at SMP Ujung Pandang Makassar. It is caused by some factors like the strategy in teaching is not interesting, the students are not given opportunity to explore their ideas and they are not involve themselves in learning process actively, they students were boring to follow the teaching and learning process. By seeing those problems then the researcher tried to use game as a teaching method which seemed they students were interested in learning English by using game instead of conventional learning. As Jones and Laura in Kuling (2010) stated that game is an interesting activity for the students. They students can learn while they are playing with their friends. It can guide the students in communicating efficiently and properly with their peer. Beside that it can be very helpful for the teacher of foreign language in a number of ways, it can brighten up the class and bring more variety into the language lesson particularly in teaching vocabulary. Finally, this method is expected to attract the students to learn English vocabulary.

There are many techniques that can help the students to enlarge and increasing their vocabulary. That is why the researcher would apply one good technique in teaching English vocabulary. One of the techniques is a game called CVC word game.

Based on the explanation above, it can be concluded that the teacher would find the suitable technique in teaching vocabulary. A game is one technique that can be used in teaching vocabulary for the students. In other word, the researcher was attracted to conduct a research entitled "The use of CVC Game Strategy in increasing the Students' Vocabulary at The Second Year of SMP Ujung Pandang Makassar”.

\section{Problem Statement}

The problem statement of this research is "Does the Use of VCV Word Game Strategy Increase the Students' Vocabulary at the Second Year of SMP Ujung Pandang Makassar?”

While the objective of the research was to find out whether or not CVC Game can increase the students' Vocabulary at the second year of SMP Ujung Pandang Makassar?

Referring to the research problem, the result of the study hopefully can give a useful contribution and information for the teacher and other researcher. Particularly, it is expected that this strategy can be used in teaching English vocabulary in order o increase the students' vocabulary mastery.

The scope of this research focused in teaching vocabulary by using CVC Game Strategy for the second year Students of SMP Ujung Pandang Makassar. The research was limited in measuring the students' noun and verb.

\section{Review of Related Literature}

This part deals with the previous related studies, theories or concept related to the thesis' topic, resume, conceptual framework and hypothesis of the research.

\subsection{Previous Related Findings}

Dami (2013) in his research said that by using the effect of five states word exercise in teaching and learning vocabularies make the students easily to understand and memorize them. Fonirin (2012) conducted a research by using scrabble word game found that the students was effective to increase their English vocabulary, can encourage the students' ability in learning vocabulary, make the students active and enjoying the learning process. Jeramah (2011) said in her finding that the use of word snake game can increase the students' vocabulary mastery in her research. It is proved that the result of post-test is greater than pre-test $(6.4>7.4)$. While Kuling (2010) in her research found out the use of bingo game can improve the students' vocabulary and motivate the students' interest in learning English. According to Herrel in Himawanto (2015), stated that there are different types of vocabulary namely: 1. Reading Vocabulary; 2. Listening Vocabulary; 3. Writing Vocabulary; and 4. Speaking Vocabulary.

Visual aids are things that you can look at, such as a film, model, map or slides to help you something or to remember easy vocabularies (Collins Dictionary: 2019). While according to Arsyad in Hanapi (2016) said that there are three kinds of media that can use to teach and learn vocabulary easily such as visual media, audio media and audio visual media. Sangadah (2015) in her research said that the students' vocabulary mastery can be improved by using visual traf- 
fic sign. She found out that there was a significant difference before and after the using of visual traffic sign in learning vocabulary.

\subsection{Some Pertinent Ideas}

Richards and Renandya (2002) define that vocabulary is a core component of language proficiency and provides much of the basis for how well learners speak, listen, read and write. Without an extensive vocabulary and strategies for acquiring new vocabulary, learners are often achieve less than their potential and may be discouraged from making use of the language learning opportunities around them such as listening to the radio, listening to native speakers, using the language in different contexts, reading or watching television. Hatch and Brown (1995) indicated vocabulary is central to language and is of great significance to language learners. Words are the building blocks of a language since they label objects, actions, ideas without which people cannot convey the intended meaning.

Every person must have vocabulary for communicating with others, it is very significant element of language, and by using vocabulary he/she can express their ideas. Even though, vocabulary does not always affect in the fluency of language. There are some English aspects that must be known and mastered by learners, such as grammar, pronunciation, diction and so on. But vocabulary still becomes requirement for mastering a language. While in Webster English Advanced Dictionary in Fonin (2012) concluded that the definition of vocabulary such as: 1) the stock of words used by particular people, class, person and a number of occupation and profession; 2) a list of word collection/language phrase, branch of science; 3) the word of language; and 4) any collection of sign of symbol constituting means/a system or on verbal communication.

After looking at the definition above, the researcher concluded that vocabulary is the meaning of the words of the English language in broadest sense used not only in speaking but also in reading, writing and listening. The meaning of the vocabulary is total number of words and it is used by a person that has meaning and function.

Regarding to the important of vocabulary expansion is the students' studies, the English teachers should know some effective ways to teach vocabulary. The students should be active and should participate in every exercise during class hour. Lewis and Hill (1990) point out the ways of explaining new vocabulary and helping to fix it in students' mind such as: 1) Demonstrate. The demonstration both helps to make the meaning clearer, and helps to fix the word in the students' mind; 2) Use the real thing. Teachers become so pre-occupied with teaching that sometimes they explain, or even draw on the blackboard things which are immediately available in the room. Sometimes the explanation is more complicated than pointing; 3) Draw or sketch. Teacher do not to be an artist to make simple sketches which illustrate meaning, particularly if they bear in mind the advice given above about teaching contrast rather than meaning itself; 4) Use the blackboard to show scales or grades. The use of scales can help the students get the point. Words like cool orange (color) or probably maybe explained by presenting them with group or related words; 5) Antonyms. It is easy to give the wrong impression by, for example equating little and small. Students should train to looking for the new one that makes them a struggle to get it; 6) Synonyms. Sometimes it is helpful particularly with relatively important word or passive vocabulary to provide a quick synonym explanation; 7) The dictionary. One technique for explaining these which teacher too frequently overlook is asking the class whether anybody knows the word, individual students to learn things outside the classroom, and if not, asking one or more students to look the word up in a dictionary; 8) Verbal explanation. Some language items are best explained by using in a variety of context, with the teacher commenting on the use. It is important with such explanation to use more than one context to avoid any incidental features of that particular context; and (9) Translation. Although some teachers over use this technique, it is equally true that the others under use it. Some students it is seen as boring and traditional. For some words, however the only sensible ways to explain is by translation.

The concept of CVC word game strategy according to Roach (1987), the words vowel and consonant are very familiar one. Vowels are sound in which there is no obstruction to the flow of air as it passes from the larynx to the lip, while consonant are sounds in which no doubt that sounds like s and d, but the consonant found at the beginning of word such as y(yes) and w (wet). They are called semivowels by many writers. The most important thing to remember about these phonemes is that they are phonetically like vowels but phonologically like consonants.

CVC word game strategy is a word containing consonant, then a vowel, then a final consonant. Consonants are all the non-vowel sounds, or their corresponding letters: A, E, I, O, U and sometimes Y are not consonant. A vowel is a letter of the alphabet (a, e, I, u, o and sometimes y) that represents a speech sound created by the relatively free passage of breadth through the larynx and oral cavity. For example cat, $\mathrm{C}$ and $\mathrm{T}$ are consonants and $\mathrm{A}$ is vowel. Means the letter of $\mathrm{y}$ is a consonant when it is the first letter of a syllable that has more than one letters, and the letter $\mathrm{y}$ is a vowel when it is anywhere else in the syllable. For example, y as a consonant such words yes and yam, and y as a vowel gym. (http://boggleworddesl.com). 
CVC words game consist of three letters involved and these three letters pose a significant part in terms of helping student learn more words after the standard alphabet. For example of CVC words are: bag, fan, cab, fat, hen, do, log, gum, and etc.

There are some stages in playing CVC word game, they are: a). the researcher divides the students into five groups, one group consist of four or five students; b). the researcher ask the students about vowel and consonant; c). the researcher explains about CVC word game to the students and the researcher shows the worksheet of CVC word game; d). the researcher divides the worksheet that has been prepared; e) the researcher explains how to work the test; f) the researcher gives time for the students for 60 minutes; g) after that the students who are more quickly did the correct answer will be the winner; and $\mathrm{h}$ ) the students give applause to the winner.

\section{Method of the Research}

In this research, the researcher used pre-experimental method which has three steps namely pre-test, treatment and post-test. There was only one class.

This researcher applied pre-experimental design with one group pre-test and post-test. This design involved one group pre-test (oi), treatment (X) and post-test (o2). The systematic design of this research is presented as follows:

Pre-test Treatment

Post-test

Where:
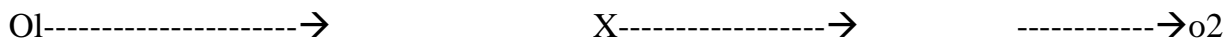

$\mathrm{O} 1=$ the result of the students' pre-test

$\mathrm{X}=$ the treatment

$\mathrm{O} 2=$ the result of the students' post-test

There were two variables in this research namely: independent and dependent variables. Independent variable was the use of CVC word game strategy in teaching vocabulary and dependent variable was the students' vocabulary mastery.

The population of this research was the second grade students of SMP Ujung Pandang Makassar in 2018/2019 academic year. It consisted of two classes VII 1 and VII 2, each class consisted of 23 students. The total population was 46 students.

The researcher applied purpose sampling technique. The researcher took VII 1 which the total sample was 23 students. This was chosen by the researcher because the students' vocabulary mastery was very low.

In collecting the data, the researcher used objective test which consisted of 30 items. This test was done in order to know the students' vocabulary mastery in pre-test and post-test. The pre-test was intended to find the students' prior knowledge of English vocabulary while post-test was intended to find the students' vocabulary mastery after the treatment by using CVC word game strategy.

To collect the data, the researcher used three steps namely

1. Pre-test. The pre-test was given just to find out the students' prior knowledge of vocabulary before the treatment by using CVC word game strategy.

2. Treatment. The treatment was done for four meeting by using CVC word game strategy in teaching vocabulary. Each meeting took 90 minutes.

3. Post-test. After given treatment the researcher provided post-test to find out the students' result after treatment.

\section{Finding and Discussion}

This par deals with the finding of the research and the discussion of the findings. The findings are ordered in line with the problem statement stated in the introduction part. In discussion part, arguments and further interpretation of the findings are given.

The findings of the research dealing with the students' scores of the research activities such as pre-test and post-test, the frequency and the rate percentage of the students' score, the main score, standard deviation of pre-test and post-test, t-test value and hypothesis testing.

The result of the students pre-test was very low. It can be seen that 1 student got 0 result classified as poor, 1 student got 36.6 classified as poor, 1 student got 46.6 classified as poor, 5 students got 50 classified as poor, 3 students got 55 classified as fair, 1 student got 58.3 classified as fair, 2 students got 60.5 classified as fair, 5 students got 63.3 classified as fair and 3 students who got 65.3 classified as fair.

The result of pre-test of the second grade students of SMP Ujung Pandang Makassaar showed that the total scores was 1,276 from the total number of 23 students. From this result, it could concluded that the students were very low in 
answering their vocabulary test. In this case, the result of the students' vocabulary mastery was very low.

After giving treatment by using the VCV Word Game Strategy the researcher found out that the strategy was effective in improving the students' mastery of vocabulary by giving post-test. In the post-test, the researcher found out that many of the students were able and easy in answering the question given. They were enthusiasm to do the test and it seemed of the expression on the students' faces when doing the test. Besides that they did the test so fast and collected their worksheet before the time finish.

After the post-test, the researcher found out the result of the test was better than when comparing before and after using the CVC word strategy. After tabulating the post-test, the researcher found that there was 1 student got 70 which was classified as fairly good, one student got 71.6 which was classified as fairly good, one student got 73.3 which was classified as fairly good, 2 students got 75 which was classified as fairly good, 4 students got 80 which was classified as good, 2 students got 83.3 which was classified as good, 2 students got 85 which classified as good, 1 student got 86.5 which was classified as very good, 5 students got 88.3 which was classified as very good, 2 students got 91.6 which was classified as very good and got 93.3 which was classified as very good.

After concluding the result between pre-test and post-test, it showed that there was a significant difference of the total scores of pre-test $(1,276)$ and post-test was $(1,887.6)$.

Based on the data elaborate above, it was considered that there was a significant difference of the students' vocabulary mastery before and after doing the treatment. It means that the use of CVC word game strategy in learning vocabulary was suitable because it could increase the students' vocabulary of the second grade students of SMP Ujung Pandang Makassar.

\section{Conclusion and Suggestion}

This chapter deals with the conclusion and suggestion of the research.

This strategy was successfully in increasing the students' vocabulary by using CVC word game strategy. The implementation of CVC word game strategy provided the students opportunities to answer the questions, to dramatize and style of recitation materials given during the teaching and learning process of vocabulary. It is expected that the teacher can apply this strategy in their vocabulary subjects since the students are happy in doing their tasks and answering the questions.

Based on the result of the data analysis, research findings and discussion in the previous chapter the researcher formulates a conclusion as follow:

The use of CVC word game strategy as treatment of the research was applied in teaching vocabulary. The students' vocabulary in pre-test was 55.5 score which could be categorized as fair, while on the students' vocabulary was increase in post-test was 82.06 which could be categorized as good. Based on the data of analysis in pre-test and post-test above showed that none of the students got excellent in the test.

The application of treatment by using CVC word game strategy in teaching and learning vocabulary could increase the students' achievement from 55.2 to 82.5 scores. It means that the treatment has increased the achievement of the students' post-test.

In relation to the conclusion above, the researcher formulates some suggestions below.

1. The researcher suggests for the English teachers to use CVC word game in teaching and learning process particularly in teaching vocabulary.

2. It is suggested that the English teachers should be creative in encouraging the students' motivation and interest through active learning to increase the students' vocabulary.

3. The teachers should be creative to manage materials and techniques for teaching vocabulary to the students for example by using CVC word game.

4. The English teachers should pay more attention to the students who had not participated in learning activity and always encourage them to take part in learning.

5. The teachers are expected to increase the intensity of using games.

6. It is also suggested that the English teachers should create exciting atmosphere in order to motivate the students in the classroom activities and get fun.

\section{References}

Dami, Herbinus. (2013). The Effect of Using Five Stages Word in Building the Students Vocabulary of the Tenth Grade Students at SMA Kristen Kandosapata Makassar. Thesis STKIP-YPUP Makassar.

Dawson, Collin. (1985). Teaching as a Foreign Language. Hong Kong. Collins, W. (n.d). Collins Dictionary. Retrieved November 11, 
2019, from Collins:https//www.collinsdictionary.com/visual media.

Fonirin, Johannes. (2012). Increasing the Students' Vocabulary Through Scrambled Word Game of the Second Year Students at SMA Jaya Negara Makassaar. Thesis: STKIP-YPUP Makassar.

Gay, L. R. (2006). Educational Research: Competencies for Analysis and Application of Dictionary. New York: MC Graw Hill and Book Company.

Hanapi. (2016). Teaching and learning Vocabulary by Using Visual Media to Students. IAIN Raden Intan Lampung.

Hatch, E. and Brown, C. (1995). Vocabulary, Semantics, and Language Education. New York: Cambridge University Press.

Himayanto, F. R. (2015). The Effectiveness of Teaching Vocabulary by Using Audio Visual toward Vocabulary Mastery At SMP 3 Kedungwaru.

Jeraman, Eduardus. (2011). Increasing the students' Mastery of English Vocabulary Through Word Snake Game. Thesis: STKIP-YPUP Makassar.

Nunan, David. (2004). Task Based Language Teaching. University of Hong Kong.

Richards, Jack C. and Renandya, Willy A. (2002). Methodology in Language Teaching: An Anthology of Current Practice. Cambridge: Cambridge University Press.

Roach, Peter. (1987). English Phonetics and Phonology.

Sangadah, N. (2015). The Effectiveness of Teaching Vocabulary by Using Visual Traffic Signs to Improve Vocabulary at Seventh Grade Students of MTS Prembun. 